\title{
РОЗБУДОВА УКРАЇНСЬКОЇ ФРАЗЕОЛОГІї: ІНДИВІДУАЛЬНО-АВТОРСЬКІ ФРАЗЕОЛОГІЗМИ ЛІНИ КОСТЕНКО
}

\author{
АННА ФІЛІП'ЯК \\ Університет імені Адама Міцкевича, Познань - Польща \\ afilipiak66@gmail.com; ORCID: 0000-0001-5203-194X \\ ROZWÓJ UKRAIŃSKIEJ FRAZEOLOGII: \\ AUTORSKIE FRAZEOLOGIZMY LINY KOSTENKO
}

\author{
ANNA FILIPIAK \\ Uniwersytet im. Adama Mickiewicza, Poznań — Polska
}

\begin{abstract}
STRESZCZENIE. Niniejszy artykuł poświęcono fenomenowi dynamicznego rozwoju ukraińskiej frazeologii, na który niewątpliwie ogromny wpływ ma elitarna osobowość językowa Liny Kostenko. W artykule określono aktualny stan ukraińskiej frazeologii, uwzględniając najbardziej znaczące zmiany oraz rodzaje autorskich transformacji związków frazeologicznych. Aktualność pracy uwarunkowana jest koniecznością teoretycznego i praktycznego zbadania specyfiki funkcjonowania związków frazeologicznych w spektrum struktury, semantyki i stylistyki tekstu pisarki, a także określenia jej idiostylu. Analizie poddano poszczególne autorskie frazeologizmy stworzone i wykorzystywane przez pisarkę zarówno w poezji, jak i w prozie, wykorzystując strukturalno-semantyczny rozbiór poszczególnych związków frazeologicznych. Wnioskujemy, że oprócz tworzenia nowych wyrażeń, w szczególności aforyzmów, pisarka aktywnie przekształca frazeologizmy, stosując podwójną aktualizację, eksplikację, substytucję, kontaminację, a także za pomocą zmiany strukturalnego składu stałych wyrażeń z zachowaniem celu wypowiedzi.
\end{abstract}

Słowa kluczowe: frazeologia, autorskie frazeologizmy, indywidualny styl, Lina Kostenko 


\title{
UKRAINIAN PHRASEOLOGY DEVELOPMENT: INDIVIDUAL IDIOMS CREATED BY LINA KOSTENKO
}

\author{
ANNA FILIPIAK \\ Adam Mickiewicz University, Poznań — Poland
}

\begin{abstract}
This article focuses on the phenomenon of Ukrainian phraseology whose development has undoubtedly been greatly influenced by the elite lingual personality of Lina Kostenko. The current state of Ukrainian phraseology is described, including most significant changes and types of transformations of idioms made by authors. The topicality of this work is accounted for by the necessity of theoretical and practical study of the phraseological units functioning in the spectrum of structure, semantics and text stylistics, as well as the study of idiolect and idiostyle of Lina Kostenko. Individual idioms, created and used by Lina Kostenko, both in her poetry and in prose, and peculiarities of their functioning are investigated through the application of structural and semantic analysis. The author of the article concludes that in addition to creating new expressions, especially aphorisms, the writer actively transforms idioms by applying explication, substitution, contamination, as well as by changing the structural composition of fixed phrases while preserving the purpose of the expression.
\end{abstract}

Key words: phraseology, individual idioms, individual style, Lina Kostenko

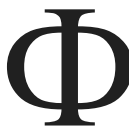

разеологія української мови була та залишається популярною лінгвістичною галуззю, що приваблює науковців, оскільки вона найбільш виразно репрезентує національну специфіку мовлення та передає його характер, створений народом протягом віків, а проблема ії опису є важливим елементом характеристики художнього стилю та характеру індивідуальної поетики автора. Фразеологічні одиниці (далі ФО) як образні засоби, які вживають у художньому тексті, характеризують відтворюваність, метафоричність, функціювання 3 метою створення відповідного експресивного ефекту, вираження емоційності. ФО містять оцінку (негативну чи позитивну) того чи того явища. Їх також використовують для вербалізування стереотипної ситуації. Фразеологізми - свідчення духовної або матеріальної культури. Вони відзначаються міфологічним або біблійним походженням, мотивуються легендами, анекдотами, можуть характеризувати жести, почуття чи відчуття та ін. Без сумніву, ФО відіграють важливу роль у творенні мовної картини світу, образно відображаючи матеріальне й духове життя народу, а фіксуючись у фразеологічній картині світу, вони відтворюють мовну свідомість носіїв відповідної лінгвокультури [Космеда, Прасол 2014: 77-83]. Зазначмо також, що фразеологізми несуть у собі не тільки предметну, але й естетичну інформацію. Їх уживають майже в усіх стилях мовлення, вони мають чітко 
виражене стильове призначення, що залежить насамперед від їхнього емоційного забарвлення.

Швейцарський мовознавець Ш. Баллі свого часу зауважив, що „сполучення утворює фразеологічну єдність, якщо слова, що входять до нього, утратили всяке самостійне значення, та воно притаманне сполученню загалом, а до того ж значення це нове, не дорівнює сумі значень його складників" [Баллі 1961: 97] (переклад автор. - А. Ф.), тобто Ш. Баллі надав фразеологізму статусу лексичної одиниці, але такої, що має більш складний характер. На думку зазначеного вченого, фразеологізм складається з кількох слів, що є самостійними одиницями, та вони структуровані за певним незмінним порядком, у якому не допускається зміна позиції чи видалення будь-якого компонента. Дослідник також указує на те, що, хоч ці принципи є, безумовно, панівними, утім трапляються фразеологізми, що „не відповідають цим трьом умовам”, а „деякі слова звороту можуть бути замінені іншими” [Баллі 1961: 98] (переклад автор. - А. Ф.), переважно в авторських, трансформованих фраземах. Ідеться про стійкість, неподільність і цілісність значення. Це основна характеристика фразеологізму, головний критерій, що дає змогу відокремити його від вільного сполучення слів.

Фразеологічна система відкрита й рухома, оскільки деякі фразеологізми можуть застарівати й розширювати значення, що викликає потребу створювати нові фразеологічні словники. ФО, як і слова, можуть бути однозначними й багатозначними. Напр., однозначними є вирази ахіллесова $n$ 'ята чи вавилонське стовпотворіння. Два й більше значень мають такі одиниці, як бити чолом, брати (взяти) своє, дати (давати) слово, висіти в повітрі, золоті руки та ін. Крім того, багатозначність і синонімія означених фразеологізмів тісно пов’ язані, оскільки нове значення тієї чи тієї фразеологічної одиниці сприяє появі нових семантичних зв'язків у сфері використання стійких словосполучень, і це, безумовно, призводить до виникнення й розширення відповідного синонімного ряду.

Важливу роль серед складників мовної структури художнього тексту відіграє його фразеологія, оскільки фразеологізми є саме тими елементами мови, що вживаються в конкретній мовній ситуації. Наголосімо, що автор не добирає їх навмисне, спеціально, натомість уживає автоматично, не зосереджуючись на їхньому зв'язку з ідейними та художніми настановами тексту.

Отже, можна стверджувати, що в більшості випадків добирання та використання ФО зумовлені мовною традицією. Характерні риси ФО, тобто експресивність, метафоричність та емоційна насиченість, за умови їхнього використання в мові художньої літератури надає текстам національного колориту. Добирання фразеологічних засобів зумовлене проблематикою тексту. На ньому позначається ідеологія сучасного суспільства (членом якого $є$ автор), а це може спричинити використання в тексті словосполучень-ідеологем чи 
пропагандистських штампів. Нерідко зазначене актуалізує загальновживані фразеологізми із соціальним спрямуванням, фразеологізми-фольклоризми.

Індивідуально-авторський стиль письменника - складне явище, що формується системою різноманітних чинників. Рисами ідіостилю письменника вважають стилістичні засоби, здатність до моделювання відповідних прагматичних ефектів, орнаменталіки, конкретних засобів та способів їхнього організування. Указані аспекти є основою аналізу особливостей ідіостилю письменника, що виразно виявляються в системі фразеології.

Використання фразеологічного матеріалу, як уважає Ю. Кохан, можна кваліфікувати як вияв творчої індивідуальності автора. Назвемо деякі риси письменницького ідіостилю щодо використання ФО: надання переваги окремим способам трансформації, частота їхнього вживання, характер застосованих стилістичних ефектів чи зв'язок з ідейно-художнім задумом та зображуваними в тексті реаліями. Типовими прийомами можуть бути, напр., заміна компонентів фраземи словами, що мають зв'язок із зображуваними реаліями. Простежуємо також такі процеси, як подвійне актуалізування фразеологізмів, тобто обігрування прямого значення складника вислову. Близьким до цього прийому є введення до складу ФО компонентів, що дають змогу сприймати фразему то як вільне, то як нерозкладне сполучення слів [Кохан 2003: 8-10]. Названий вище вчений зауважує також, що „значний вплив на добір фразеологізмів мають особливості світобачення письменника, яке може бути реалістичним, романтичним, піднесено-урочистим, насмішкувато-іронічним тощо. Тип авторського світобачення може зумовлювати добір фразеологічних одиниць з відповідним емоційно-експресивним забарвленням" [Кохан 1999: 2016].

Аналізуючи індивідуальний стиль письменника, звертаємо увагу на те, що деякі мовні одиниці автор уживає значно частіше порівняно з іншими письменниками. Це важливо, тому що досліджувати особливості ідіостилю письменника, специфіку використання ним того чи того мовного засобу можна лише тоді, коли такі мовні одиниці є часто вживаними. Це можна відстежити, проаналізувавши дібраний письменником фразеологічний матеріал. Під час дослідження індивідуально-авторських стилів учені використовують поняття слова-фаворити [Кохан 1999: 218]. Звернімо увагу, що використання автором у його тексті окремих ФО зумовлене не лише їхніми виражальними та стилістичними властивостями, але також і преференціями автора. Відповідно, такі часто вживані письменником сталі сполучення слів доцільно назвати фраземами-фаворитами. Виявом авторської індивідуальності й тією рисою, що відрізняє стиль одного автора від стилів інших письменників, є факт надання переваги окремим ФО і створення за допомогою них певного емоційно-стилістичного забарвлення тексту загалом. Ю. Кохан зауважує також, що на формування ідіостилю впливає характер використання письменником фразеологічних засобів, що може виявлятися в типовості чи нетиповості стій- 
ких сполучень слів для різних форм опису 一 пейзажів, портретів, сюжетних подій, ліричних відступів тощо, у стильовій належності стійких сполучень слів, їхньому емоційному забарвленні, виконуваних ними функціях [Кохан 1999: 217].

Фразеологічні трансформації в художньому тексті відображають індивідуально-авторське сприйняття дійсності, тобто визначають ідіостиль письменника. Л. Щербачук стверджував, що „оказіональні зміни форми й семантики фразеологічної одиниці варто кваліфікувати як ускладнений, творчий процес, що здійснюється з волі письменника: оказіонально змінені фразеологічні одиниці - як індивідуально-авторську фразеологію, що служить засобом збагачення письменником літературної мови" [Кохан 2003: 16].

Творчість Ліни Костенко сьогодні $є$ важливим явищем сучасної української поезії, що значно впливає на весь ії розвиток. Особливості індивідуального поетичного стилю письменниці — це передусім висока культура поетичного вислову, новаторство, інтелектуальність, високий рівень мовної свідомості й інтертекстуальність. Поетеса як одна 3 найбільш відомих авторів в Україні володіє надзвичайною образністю висловлювання, що, безумовно, значно збагачує сучасну українську мову. У щоденне вживання ввійшло вже чимало авторських неологізмів і трансформованих фразеологізмів, властивих стилю письменниці. Нові (авторські) вислови поетеси, трансформації в зафіксованих сполученнях слів та неологізмах, є неоціненним джерелом для подальшого розвитку мови.

Звернімо увагу й на те, що поетичне мовлення Ліни Костенко насичене широким розмаїттям фразеологізмів, серед яких виявляємо узуальні й трансформовані фразеологізми, а також крилаті вислови та афоризми, що вдало передають і закріплюють художню та естетичну оцінку дійсності, створену письменницею. Зауважмо також, що узуальні фразеологізми, тобто фразеологізми, зафіксовані в словниках, є лінгвістичними об'єктами, до яких звертається багато письменників.

Крім традиційного терміна фразеологізм, прийнятним є також термін, що визначає індивідуально-авторський фразеологічний новотвір - індивідуальний /оказіональний / контекстний фразеологізм. Роль таких новотворів у мові Ліни Костенко виявляється в умінні оригінально поєднати слова, підібрати незвичне означення, а також зв'язати різні в семантичному або часовому контекстах поняття. Прикладами таких новотворів $є$ крилаті вислови та афоризми. Безперечно, афоризми здатні створювати тільки ті люди, які характеризуються лінгвокреативністю: це вимагає наявності досконалої мовної компетенції, дотепності й винахідливості, уміння сприймати смисл тексту, гнучко мислячи та неоднозначно сприймаючи світ. Багато афоризмів стають життєвими девізами завдяки фіксації в структурі одиниць на позначення чуттєвих цінностей, образів, переконань, а також відповідних знань чи поглядів. 
У поетичній творчості Ліни Костенко можна виокремити такі крилаті вислови, що поєднують смислові та культурні інтерпретаційні схеми, порівн.: Здушили сльози - не виходь на люди. Болить душа - не виявляй на вид; Страшні слова, коли вони мовчать; Якщо платити злочином за злочин, то як же й жити... на землі; Душа летить в дитинство, як у вирій, бо їй на світі тепло тільки там; Де воля спить, ї̈ ще й приколишуть; Поразка - ие наука. Ніяка перемога так не вчить; Сдиний, хто не втомлюється, - час; Самотнім добре - жодної розлуки; Всі слова уже були чиймись; А слово струм. А слово - зброя. А віще слово - вічове; Не було епохи для поетів, але були поети для епох!

Письменниця створила чимало авторських фразеологізмів, що закріпилися в іiі ідіостилі. Ці вирази вживають у повсякденному житті для позначення певних явищ чи процесів, напр.: Як на полі мінному - 'перебувати в небезпечному становищі, ризикувати'; Моя душа відкрилась, як Сезам - 'бути готовим сприймати почуття, ділитись власними переживаннями’; Говори очима - 'виявляти свої почуття й думки за допомогою погляду, установлювати зоровий контакт зі співрозмовником'; Чого ж ви так дивитесь в душу мою? - дивитися в душу - 'проникати у чийсь внутрішній світ, розуміти думки іншої людини'; Полюють в полі на три тополі - (ірон.) 'займатися безглуздою непотрібною справою'; Заржавіла лампа Аладина — 'річ, що втратила свої функційні можливості'; Любити до оніміння — 'найвищий рівень вияву почуттів, безмежно'.

Індивідуально-авторські фразеологізми, створені письменницею, без сумніву, окреслюють її творчу манеру. Аналіз цих виразів, з'ясовані особливості їхнього добору в художньому тексті в окремих мовних ситуаціях, а також характерні структурно-семантичні трансформації, засвідчують, що фразеологічні засоби, які змодельовані авторкою в тексті, надають йому неповторного характеру, відповідно формуючи потужний характер ідіостилю та ідіолекту авторки.

У творчості Ліни Костенко виявляємо чимало трансформованих нею фразеологізмів. Для авторки такий процес необхідний, щоб оновити семантику й структуру ФО, зберігаючи при цьому фразеологічний образ. Трансформація обов'язково передбачає стилістичну мету. Переважно це уточнення чи розширення значення ФО у зв'язку з конкретною мовленнєвою ситуацією.

У художніх текстах може бути зафіксовано поєднання в одному стійкому виразі і прямого, і переносного значень, тобто відтворено подвійну актуалізацію ФО. У прозових творах Ліни Костенко поширені фразеологізми з подвійною актуалізацією. Під час подвійного актуалізування може відбуватися й лексико-граматичне оновлення всього фразеологічного виразу, напр.: грають вирішальну роль - словниковий відповідник грати (зіграти) роль 'мати певне значення, виконувати відповідні функції або видавати себе за 
когось'. Ліна Костенко розширює граматичну структуру за рахунок сполучних можливостей компонентів і змінює лексичне значення ФО. Така експлікація стійкого вислову виправдана не лише лінгвістично, а й психологічно, оскільки при цьому фразеологізм зіграти вирішальну роль передає семантику 'мати важливе значення, остаточно вплинути на щось’. У реченні Коли ж з гуркотом упала залізна завіса відбувається часткове подвійне актуалізування фразеологізму піднімати / підняти завісу — 'розкривати приховане'. Відбувається оновлення лексико-граматичного плану ФО з розширенням іiі складу за рахунок сполучних можливостей компонентів й усталення його як відомого фразеологізму, при цьому конкретизується значення, обіграється потенційна семантика слова завіса в спеціально створеному авторкою контексті.

Часткове подвійне актуалізування фразеологічного значення відбувається в реченні Запорошувати очі наступних поколінь. Потенційна семантика компонента запорошувати обіграється в спеціально створеному контексті. Загальновживаний варіант фразеологізму замазувати / замазати очі кому'відвертати чию-небудь увагу; обманювати когось'.

У реченні Двір купався в розкошах Ліна Костенко трансформує фразеологізм купатися в золоті, що означає 'жити в багатстві, щасливо, мати всього вдосталь'. Відбувається оновлення лексичної структури фразеологізму шляхом заміни одного з компонентів синонімом зі збереженням значення та основної структури ФО.

Субституція одного 3 компонентів репрезентована у фразеологізмі обростаєм абсурдом - словниковий варіант обрости мохом (жарт.) означає 'постаріти, зістарітися, ставши байдужим до всього'.

Трансформування ФО за допомогою експлікування (розкриття змісту певної єдності, під час якого іiі частини набувають самостійного існування й можуть відрізнятися одна від іншої) структурного складу спостерігаємо у ФО иіни підскакують як скажені, порівн.: як скажений - 'утрачаючи самовладання або не стримуючись у гніві; несамовито, нестямно': тут додано дієслівний компонент підскакують.

Можливим є також майже повне змінення структурного складу ФО зі збереженням мети висловлювання, напр.: Дехто вже навіть готовий похилити жалобні прапори..., де словниковий варіант фразеологізму викидати білий nрапор - 'здаватися, припиняти боротьбу, суперечку' (білий колір - загальноприйнята символіка припинення боротьби).

Безперечно, унесок Ліни Костенко в розвиток сучасної української мови та фразеології зокрема надзвичайно важливий. Її досконале вміння оперувати словом та переносити його в інший семантичний простір сприяє створенню нових, індивідуально-авторських ФО, що збагачують і прикрашають літературну мову українців. Чимало усталених виразів, спроєктованих Ліною Костенко, увійшли в щоденне розмовне мовлення. Крім творення нових уста- 
лених виразів, зокрема й афоризмів, письменниця активно трансформує ФО, використовуючи подвійну актуалізацію, експлікацію, субституцію, контамінацію та змінюючи структурний склад ФО зі збереженням мети висловлювання.

Зауважмо також, що сьогодні мовна культура значно впливає на формування нових фразеологізмів, насамперед афористичних, що належать до его-текстових конструкцій. Зміни в соціальному та політичному житті суспільства призводять до актуалізування тих фразеологічних одиниць, що із часом стали застарілими, а також сприяють творенню нових виразів, що, як доводить проаналізований матеріал, яскраво демонструє й Ліна Костенко. Більшість усталених виразів, створених Ліною Костенко, мають надзвичайну семантичну гнучкість, суспільство сприймає їх позитивно, активно використовуючи. Подібні нові одиниціне лише частотні в мовленні, але й закріплюються в мові.

\section{Список використаної літератури}

Балли Ш., Франиузская стилистика, Москва: Изд-во иностр. лит-ры, 1961.

Космеда Т. А., Прасол О. П., “Політичний” фразеологізм у мовній свідомості галичан $i$ поляків: проблема трактування, [в:] „Вісник Дніпропетровського університету”, 2014, № 11, c. 77-83.

Кохан Ю. І., Фраземіка в системі ідіостилю письменника (на матеріалі художньої прози Олеся Гончара і Павла Загребельного), дис. ... канд. філол. наук, Харків 2003.

Кохан Ю. І., Добір фразеологічного матеріалу як фактор формування ідіостилю письменника (на матеріалі прози Олеся Гончара), [в:] „Вісник Харківського університету”, 1999, № 426, с. 216-220.

\section{Spysok vykorystanoi literatury [References]}

Balli S., Francuzskaya stilistika [French Stylistics], Moskva: Izd-vo inostr. lit-ry, 1961.

Kosmeda T. A., Prasol O. P., "Politychnyi" frazeologizm u movnii svidomosti halychan $i$ poliakiv: problema traktuvannia ["Political" Phraseology in the Language Consciousness of Galicians and Poles: the Problem of Interpretation], [v:] „Visnyk Dnipropetrovskoho universytetu”, 2014, № 11, s. 77-83.

Kokhan Y. I., Frazemika v systemi idiostyliu pysmennyka (na materiali khudozhnoi prozy Olesia Honchara i Pavla Zahrebelnoho) [Phraseology in Idiostyle of the Writer (Based on Material of Artistic Prose Written by Oles Gonchar and Pavlo Zagrebelny)], dys. ... kand. filol. nauk, Kharkiv 2003.

Kokhan Y. I., Dobir frazeolohichnoho materialu yak faktor formuvannia idiostyliu pysmennyka (na materiali prozy Olesia Honchara) [Selection of Phraseological Material as a Factor 
in the Formation of Idiostyle of the Writer (on the Material of Prose Oles Gonchar)], [v:] „Visnyk Kharkivskoho universytetu”, 1999, № 426, s. 216-220.

\section{Список використаних джерел}

Костенко Л. В., Записки українського самашедшого, Київ: Вид-во А-БА-БА-ГА-ЛА- МА-

ГА, 2011.

Костенко Л. В., Равнєніє на трибуну. Опис фантасмагоричного параду до 20-річчя незалежності України, [в:] „День”, 2011, № 147, с. 12.

Костенко Л. В., Триста поезій, Київ: Вид-во А-БА-БА-ГА-ЛА-МА-ГА, 2012.

Костенко Л. В., Украӥна як жертва і чинник глобалізаиії катастроф, [в:] „День”, 2003, № 76 , c. 14.

\section{Spysok vykorystanykh dzherel [References]}

Kostenko L. V., Zapysky ukrainskoho samashedshoho [Notes of a Ukrainian Madman], Kyiv: Vyd-vo A-BA-BA-HA-LA-MA-HA, 2011.

Kostenko L. V., Ravnieniie na trybunu. Opys fantasmahorychnoho paradu do 20-richchia nezalezhnosti Ukrainy [Levelling the Podium. Description of the Phantasmagoric Parade to the 20th Anniversary of Ukraine’s Independence], [v:] „Den”, 2011, № 147, s. 12.

Kostenko L. V., Trysta poezii [Three Hundred Poems], Kyiv: Vyd-vo A-BA-BA-HA-LA-MAHA, 2012.

Kostenko L. V., Ukraina yak zhertva i chynnyk hlobalizatsii katastrof [Ukraine as a Victim and a Factor in the Globalization of Disasters], [v:] „Den”, 2003, № 76, s 14. 